\title{
Adjusting a Criminal Defendant's Sentence After a Successful Collateral Attack
}

\author{
Sanford I. Weisburst $\uparrow$
}

Suppose a police officer, after an undercover drug buy in an apartment, obtains and executes a search warrant and finds a bag of narcotics and a firearm inside a locked trunk in the closet. The drug dealer, in exchange for the prosecutor's promise to drop a conspiracy count, pleads guilty to one count of possession of narcotics with intent to distribute and one count of using a firearm in relation to a drug trafficking offense. Next, the court sentences the defendant to prison. While in prison, the defendant discovers that the Supreme Court has issued a new, narrow interpretation of the "use of a firearm" statute, and the defendant concludes that his storage of the firearm in a locked trunk probably does not satisfy this new definition of "use." The defendant then moves that the district court vacate his conviction on the "use of a firearm" count. The government, while conceding that the conviction on the "use" count should be vacated, requests that the court enhance the defendant's sentence on the remaining, valid drug distribution count, for which possession of a firearm is an aggravating factor.

In the wake of Bailey $v$ United States, in which the Supreme Court issued a new, narrow definition of "use" of a firearm, ${ }^{1}$ courts have disagreed on how to adjust a defendant's remaining sentence after a successful collateral attack. ${ }^{2}$ Two adjustment schemes are potentially available when the defendant's convictions were the product of a plea agreement: ${ }^{3}$ the court could resentence the defendant on the remaining valid counts, or it could allow the government to reinstate the original indictment. ${ }^{4}$

\footnotetext{
$\dagger$ A.B. 1995, Harvard University; J.D. Candidate 1998, The University of Chicago.

116 S Ct 501, 509 (1995) (prosecutor must show "active employment" of the firearm).

2 Compare, for example, United States $v$ Mata, 1996 US Dist LEXIS 16780, *8-10 (S D NY) (holding that the sentence on defendant's remaining count can be enhanced) (collecting cases), with Warner v United States, 926 F Supp 1387, 1392 (E D Ark 1996) (holding that the sentence on defendant's remaining count cannot be enhanced).

3 A third potential approach would be for the court to leave the defendant's remaining sentence intact.

- When the defendant's convictions were the product of a trial, only the resentencing mechanism is available because there is no legal theory on which to base a remedy of reinstating the original indictment. When the defendant's sole conviction was the product of a plea agreement and was vacated on collateral attack, the resentencing option is un-
} 
Courts have evaluated the permissibility of these adjustment mechanisms using such legal tools as contract law, the court's jurisdiction, the Double Jeopardy Clause, and the Due Process Clause. Yet these legal doctrines do not definitively resolve the question of how the criminal justice system can permissibly dispose of a defendant who succeeds in collaterally attacking a conviction based on a change in the law.

Accordingly, courts need a persuasive reason to construe the legal doctrines in a certain way. Two competing interests must be reconciled. Society has an interest in punishing criminals proportionately to their conduct, ${ }^{5}$ an interest potentially frustrated by a defendant's successful collateral attack. On the other hand, defendants have an interest in avoiding an adjustment of their sentence after a successful collateral attack. Weighing these interests, this Comment concludes that courts should allow flexible adjustment of defendants' sentences, in the form of either resentencing or reinstating the original indictment. This option provides defendants with the benefit of the change in the law but prevents them from receiving an unjustified windfall. At the same time, this option protects society because, without such an adjustment of the defendant's sentence, conduct that the law still deems culpable may go unpunished.

This Comment examines the broader implications of adjusting a criminal defendant's sentence after a change in the substantive criminal law by focusing on specific issues relating to Bailey's aftermath. Part I sets forth the basic framework of the United States Sentencing Guidelines, provides a brief history of the Bailey decision, and introduces the statute that allows a federal prisoner to collaterally attack his sentence. Part II applies contract law principles to the case of a defendant who entered a plea agreement and then succeeded in vacating one of his counts. Part III examines the permissibility of resentencing on remaining counts, and Part IV evaluates the permissibility of reinstating the original indictment. Part $\mathrm{V}$ attempts to supplement the applicable legal doctrine, which is somewhat open-ended, by considering the implications of different "sentence adjustment" rules

available because there are no remaining counts to enhance.

- This Comment assumes that the sentencing schedule promulgated by the United States Sentencing Commission, and the mandatory minimum consecutive sentences for violations of criminal statutes enacted by Congress, such as 18 USC \& 924(c) (five-year minimum for use or possession of a gun during a violent or drug trafficking crime), reflect society's view of how much punishment should attach to differing degrees of criminal conduct. 
in light of various theories of punishment. This Part also discusses the types of plea agreements prosecutors and defendants would have made if they had considered the possibility of a shift in the law.

\section{CONVICTION, STATUTORY REINTERPRETATION, AND RELIEF}

Before embarking on a discussion of what happens after a defendant succeeds in a collateral attack, it is helpful to consider the steps in the process leading up to the collateral attack stage. This Part puts the post-Bailey relief issue in context by introducing the relevant sentencing guideline provisions, summarizing the change in the law effected by Bailey, and exploring the typical defendant's opportunities for relief.

\section{A. An Either/Or Relationship in the Sentencing Guidelines}

The United States Sentencing Guidelines ${ }^{6}$ ("Guidelines") create a fairly mechanical sentencing process. First, the judge uses Appendix A of the Guidelines to match the defendant's conviction to a base offense level and adjusts up or down for any specific offense or victim characteristics as the Guidelines direct. ${ }^{7}$ When the conviction includes multiple counts, counts involving substantially the same harm are sorted into distinct groups and plugged into a combined offense table to determine the combined offense level. ${ }^{8}$ Second, the judge determines the defendant's criminal history category and makes any applicable adjustments. ${ }^{9}$ Third, the judge plugs the base offense level and the criminal history category into the sentencing table, and the table indicates the sentencing range (in months). ${ }^{10}$ Finally, the judge

6 The Guidelines were enacted pursuant to the Sentencing Reform Act of 1984, Pub L No $98-473$, 98 Stat 1987, codified at 18 USC $\$ \S 3551-673,28$ USC $\$ \S 991-98$ (1994). The Guidelines became effective on November 1, 1987, see 18 USC § 3551 note (1994); Federal Sentencing Guidelines, Ch 1, Pt A(2) (West 1995) ("USSG"), and apply to offenders who commit crimes on or after that date. Continuing Appropriations, 1985-Comprehensive Crime Control Act of 1984, S Rep No 98-225, 98th Cong, 1st Sess 189 (1983), reprinted in 1984 USCCAN 3182, 3372.

7 USSG \& 1B1.1(a). The procedure for calculating the offense level is slightly more complicated where the plea establishes facts that would support conviction for a more serious offense than the one agreed to. In such a case, the court is to apply the Guideline most applicable to the more serious offense or offenses established. USSG $\$ 1 B 1.2$, commentary (n 1). For a more detailed description of the way the Guidelines are applied, see Project, Twenty-Fifth Annual Review of Criminal Procedure: United States Supreme Court and Courts of Appeals 1994-1995, 84 Georgetown L J 713, 1261-1309 (1996).

¿ USSG § 3D1.4-4.

USSG \& 1B1.1(f).

${ }^{10}$ USSG $§ 1 B 1.1(\mathrm{~g})$. 
chooses from within this range and imposes the sentence. ${ }^{11}$

The specific guideline at issue in the post-Bailey cases, ${ }^{12}$ $\S 2 \mathrm{D} 1.1(\mathrm{~b})(1)$, concerns a "specific offense characteristic" enhancement of the base offense level. It provides that, "[i]f a dangerous weapon (including a firearm) was possessed" during the commission of the offense, the sentencing judge is to "increase [the base offense level] by 2 levels." ${ }^{13}$ However, a defendant cannot receive both the $\S 2 \mathrm{D} 1.1(\mathrm{~b})(1)$ enhancement and an 18 USC $\S 924(c)(1)$ (use of a firearm in a drug offense) ${ }^{14}$ conviction because that would constitute double counting-that is, the defendant would be punished twice for the same conduct of using or possessing a firearm. ${ }^{15}$ Thus, the prosecutor faces a choice between seeking a $\S 924(\mathrm{c})(1)$ conviction or a $\S 2 D 1.1(\mathrm{~b})(1)$ enhancement on the predicate drug counts. Because a $\S 924(c)(1)$ conviction carries with it a more severe penalty than a $\S 2 \mathrm{D} 1.1(\mathrm{~b})(1)$ enhancement, prosecutors are likely to seek a $\S 924(c)(1)$ conviction. ${ }^{16}$

\section{B. A Change in Statutory Interpretation: The Meaning of "Use"}

The substantial drug problems present in the United States, in conjunction with the pervasive association between firearms and drug transactions, ${ }^{17}$ suggest the importance of $\S 924(\mathrm{c})(1)$ to the federal criminal law. ${ }^{18}$ Section $924(c)(1)$ punishes a defendant who "in relation to any ... drug trafficking crime ... uses . . a a

${ }^{11}$ USSG § 1B1.1(i) (The judge is to look "to any other policy statements or commentary in the guidelines that might warrant consideration in imposing sentence.").

${ }^{12}$ See, for example, Woodhouse v United States, 934 F Supp 1008, 1010 (C D II 1996).

${ }^{13}$ USSG § 2D1.1(b)(1).

${ }^{14} 18$ USC \& 924(c)(1) imposes a five-year minimum term of imprisonment upon a person who "during and in relation to any crime of violence or drug trafficking crime . . . uses or carries a firearm." This five-year term must be served consecutively to any other sentence the defendant receives. $18 \mathrm{USC} \& 924(\mathrm{c})(1)$ (1994). Other statutes that require the term of imprisonment to run consecutively to any other term of imprisonment are 18 USC $\$ 844(\mathrm{~h})$ (1994) (use or possession of an explosive during commission of a felony), and 18 USC § 929(a)-(b) (1994) (use or possession of a firearm along with possession of armor-piercing ammunition).

${ }^{15}$ USSG § 2K2.4, commentary (n 1, backg'd); Woodhouse, 934 F Supp at 1010.

${ }^{16}$ See, for example, Warner $v$ United States, 926 F Supp 1387, 1390 (E D Ark 1996) $(\S 924(c)(1)$ utilized rather than $\S 2 D 1.1 b(1)$ enhancement in original pre-Bailey prosecution); Woodhouse, 934 F Supp at 1009 (same); Beal v United States, 924 F Supp 913, 914 (D Minn 1996) (same); Rodriguez v United States, 933 F Supp 279, 280 (S D NY 1996) (same).

${ }^{17}$ See Lawrence M. Friedman, Crime and Punishment in American History 457-64 (Basic 1993).

${ }^{18}$ Its importance is reflected in the Supreme Court's decision to accept two cases in the past decade relating to the interpretation of § 924(c). See Bailey, $116 \mathrm{~S} \mathrm{Ct}$ at 501; Smith $v$ United States, 508 US 223 (1993). 
firearm." Before 1995, the circuit courts of appeals tended to construe "use" broadly, encompassing mere possession of a firearm. ${ }^{19}$ Thus, many defendants who had not actively employed a firearm were convicted of violating $\S 924(\mathrm{c})(1)$.

In 1995, the Supreme Court in Bailey adopted a narrow interpretation of "use" that requires "active employment" of a firearm, such as "brandishing, displaying, bartering, striking with, and most obviously, firing or attempting to fire a firearm. ${ }^{200} \mathrm{Be}-$ cause many of the defendants convicted prior to Bailey had not actively employed a firearm, they had not violated § 924(c)(1) as interpreted by the Supreme Court in Bailey. Notably, however, the Supreme Court distinguished the conduct that would support a $\S 924(c)(1)$ conviction, "active employment" of a firearm, from the conduct that would support an enhancement under $\S 2 \mathrm{D1.1(b)(1)}$ of the Guidelines, requiring only that a "firearm was possessed during the offense."21

\section{Relief for Defendants Convicted Under the "Mere Possession" Standard}

Understandably, defendants have tried to avail themselves of the new interpretation of $\S 924(c)(1){ }^{22}$ The primary avenue ${ }^{23}$ for relief is 28 USC $\S 2255$ : it essentially allows a "prisoner in

\footnotetext{
${ }^{19}$ Although these courts did not uniformly adopt the very broad "mere possession" approach (the D.C. Circuit required a connection with the drug offense), none adopted the "active employment" standard later selected by the Supreme Court. See United States $v$ Torres-Rodriguez, $930 \mathrm{~F} 2 \mathrm{~d} 1375,1385$ (9th Cir 1991) (mere possession sufficient to satisfy $\$$ 924(c)(1)); United States v Brett, 872 F2d 1365, 1370-71 (8th Cir 1989) (same); United States $v$ Bailey, 995 F2d 1113, 1116 (DC Cir 1993) (prosecutor must prove possession and "a connection between the firearm and an underlying drug offense"), revd, 116 S Ct 501, 506 (1995). But see United States v Feliz-Cordero, 859 F2d 250, 254 (2d Cir 1988) (presence of gun in dresser drawer in apartment with drugs held insufficient to satisfy $\$ 924(c)(1))$.

${ }^{20}$ Bailey, $116 \mathrm{~S} \mathrm{Ct}$ at 508 . The Court did not, however, issue a definitive interpretation of the word "carries," which also appears in the language of $\$$ 924(c)(1).

${ }^{21}$ Bailey, $116 \mathrm{~S}$ Ct at 509.

22 Due to the widespread use of $\$ 924$ (c)(1) by prosecutors, many defendants now find themselves in this situation after Bailey. For example, in the District of Columbia, the Public Defender's Office is handling over two hundred cases in which relief may be warranted in light of Bailey. United States $v$ Jefferson, 1996 WL 694176, *1 (D DC).

${ }^{2}$ Other avenues for obtaining relief exist, but are limited in their availability. A defendant might appeal his $\$ 924(\mathrm{c})(1)$ conviction on grounds of erroneous jury instruction and insufficient evidence; however, because the defendant must file a notice of appeal within ten days after the entry of the judgment, see FRAP 4(b), this outlet will aid only those defendants convicted no earlier than ten days before the Supreme Court decided Bailey. A defendant who appealed his $\$ 924(\mathrm{c})(1)$ conviction before Bailey might file a petition for rehearing, but the fourteen-day time limit after entry of judgment, see FRAP 40 (a), similarly limits the availability of this option.
} 
custody" to ask the sentencing court to "vacate, set aside, or correct" an illegal sentence. ${ }^{24}$ Although $\S 2255$ requires that a defendant make his motion within one year of the date on which the Supreme Court initially recognized a new "right,"25 this time limit is much more generous than are the time limits for filing a notice of appeal or a petition for rehearing. ${ }^{26}$

A defendant who failed to raise the argument on appeal that he now seeks to make in a $\S 2255$ motion faces the substantial hurdle of showing (1) "cause" excusing the defendant's failure to raise the issue on direct appeal, and (2) "actual prejudice" resulting from the error. ${ }^{27}$ Most courts have held that "cause" and "prejudice" exist in the post-Bailey scenario because appeal would have been futile in light of existing precedent and because the new interpretation of $\S 924$ (c)(1) renders the conviction unsupported by sufficient evidence. ${ }^{28}$ The government and most courts proceed on the unstated assumption that Bailey is retroactive to defendants whose convictions have become final, an as-

24 28 USCA \& 2255 (West 1996).

${ }^{25}$ Id. Section 2255 was extensively amended by the Antiterrorism and Effective Death Penalty Act of 1996, Pub L No 104-132, 110 Stat 1214, 1220-21 (1996). Under the old version of $\S 2255$, there was no time limit. 28 USC $\S 2255$ (1994) ("A motion for such relief may be made at any time."). Also, the old version of $\$ 2255$ did not distinguish between initial and successive motions for relief. The new $\S 2255$ imposes stringent requirements on a successive motion, requiring that such a motion be certified by a panel of the appropriate court of appeals to contain either:

(1) newly discovered evidence that, if proven and viewed in light of the evidence as a whole, would be sufficient to establish by clear and convincing evidence that no reasonable factfinder would have found the movant guilty of the offense; or (2) a new rule of constitutional law, made retroactive to cases on collateral review by the $\mathrm{Su}$ preme Court, that was previously unavailable.

28 USCA $\S 2255$. Several courts of appeals have determined that Bailey did not express a rule of constitutional law, but rather was merely an interpretation of a substantive criminal statute. Accordingly, these courts have held that a prisoner is not entitled to make a successive motion on grounds of the Bailey decision. See, for example, In re Blackshire, 98 F3d 1293, 1294 (11th Cir 1996); In re Tolliver, 97 F3d 89, 90 (5th Cir 1996).

${ }^{26}$ See note 23. In contrast to an appeal, in which any error of law is cognizable, § 2255 generally recognizes only violations of federal law that involve a "fundamental defect" causing a "complete miscarriage" of justice. Davis $v$ United States, 417 US 333, 346 (1974), quoting Hill v United States, 368 US 424, 428 (1962). See also Review of Criminal Procedure, 84 Georgetown L J at 1453-55 nn 2832-33 (cited in note 7).

${ }^{27}$ Beal $v$ United States, 924 F Supp 913, 915 (D Minn 1996), citing United States $v$ Frady, 456 US 152, 167-68 (1982); Dalton v United States, 862 F2d 1307, 1309 (8th Cir 1988).

${ }^{23}$ See, for example, Beal, 924 F Supp at 915; United States $v$ Barnhardt, 93 F3d 706, 708 (10th Cir 1996) (holding that defendant who pled guilty to a $\$$ 924(c)(1) count and thus did not appeal could make a $\$ 2255$ motion in light of the intervening change in the law effected by Bailey). But see Bousley $v$ Brooks, 97 F3d 284, 287 (8th Cir 1996) (holding that Bailey "does not resurrect a challenge to a section 924(c) conviction that has been procedurally defaulted"). 
sumption that seems justified given that Bailey announces a new interpretation of a substantive criminal statute, rather than a new rule of criminal procedure. ${ }^{29}$

Once the defendant succeeds in his $\S 2255$ motion, ${ }^{30}$ the court vacates the sentence associated with the $\S 924(c)(1)$ count. This results in a five-year decrease in the defendant's aggregate sentence, given that the five-year $\S 924(c)(1)$ sentence must be served consecutively to, rather than concurrently with, sentences for other counts. ${ }^{31}$

Where the defendant's convictions were the product of a plea agreement, two "sentence adjustment" mechanisms are potentially available to the government: ${ }^{32}$ first, the government could request that the court apply the $\S 2 \mathrm{D} 1.1(\mathrm{~b})(1)$ enhancement to the remaining counts; ${ }^{33}$ or second, the government could attempt to reinstate the original indictment. ${ }^{34}$ The next three Parts of this Comment evaluate the legal permissibility of these mechanisms.

\section{RightS UNDER THE PLEA AGREEMENT AND BACKGROUND CONTRACT LAW}

Prosecutors who want to resentence on remaining counts or reinstate an original indictment have a number of different ar-

${ }^{20}$ See, for example, United States $v$ Turner, 914 F Supp 48, 48-50 (W D NY 1996) (holding that Teague $v$ Lane, 489 US 288 (1989) and its progeny concern changes in procedural law, and therefore leave intact the rule of Davis v United States, 417 US 333, 346 (1974), that certain changed interpretations of substantive criminal statutes may be applied retroactively). This result is supported by cases involving changed interpretations of statutes other than the one at issue in Bailey. See, for example, United States v McKie, 73 F3d 1149, 1150-52 (DC Cir 1996) (21 USC \& 844(a)); United States v Dashney, 52 F3d 298, 298-99 (10th Cir 1995) (31 USC \$§ 5322(a), 5324(3)).

${ }^{30}$ The government often concedes the vacatur of the $\$ 924(c)(1)$ count where the evidence clearly did not show active employment of the firearm. See, for example, Woodhouse v United States, 934 F Supp 1008, 1010 (C D II 1996). Sometimes, the court accepts the defendant's argument despite the government's opposition. See, for example, United States v Cushenberry, 1996 US Dist LEXIS 13315, *7 (E D La) (government argued that the defendant deliberately "displayed" guns as part of a drug trafficking crime).

${ }^{3}$ See note 14 .

${ }^{32}$ The government also could decline to attempt to adjust the defendant's remaining sentence. This presents no problem from the standpoint of legal permissibility, for in our adversarial system, the government prosecutor has wide discretion in deciding not to prosecute a defendant.

${ }^{3}$ The absence of the $\$ 924(\mathrm{c})(1)$ count means that the double-counting problem has disappeared. This resentencing adjustment mechanism is feasible (disregarding legal obstacles for the moment) only if there is a remaining count to enhance. Thus, where a plea agreement resulted in only a $\$ 924(\mathrm{c})(1)$ conviction, the government must either "do nothing" or look to the "reinstatement" adjustment mechanism.

${ }^{34}$ Where the now-vacated $\S 924(c)(1)$ count resulted from a conviction at trial rather than a plea agreement, the reinstatement option would be unavailable because it rests on principles of contract law that are used to interpret plea agreements. 
guments at their disposal. Regarding resentencing, if the prosecutor's only obligation under the plea agreement was to dismiss certain counts, as is likely the case, then the prosecutor is free, within the terms of the plea agreement, to seek a sentence enhancement on the remaining counts. Thus, the terms of the plea agreement and contract law pose no hurdle to the resentencing remedy in most cases. ${ }^{35}$

Regarding reinstatement of the indictment, the terms of the plea agreement and background contract law provide more of an obstacle, for in the typical plea agreement in the post-Bailey cases the prosecutor has explicitly promised to dismiss certain charges. To reinstate the dismissed charges, then, the prosecutor must establish why he should no longer be bound by the earlier promise. The prosecutor could argue that the defendant's successful $\S 2255$ motion breached the plea agreement, thus releasing the prosecutor from his earlier promise to drop certain counts. Alternatively, the prosecutor could argue that under the contract doctrine of impossibility, the defendant should be excused from his promise to serve the $\S 924$ (c)(1) sentence but that the rights and duties of the parties need to be equitably adjusted in light of an unforeseen change in the law. As this Part will demonstrate, contract law leads to a rejection of the "breach" argument but fails to provide much guidance on the permissibility of reinstatement as an equitable remedy. Before turning to the cases, a brief introduction to plea agreements helps frame the issues.

\section{A. Plea Agreements: An Introduction}

When the defendant and the prosecutor enter a plea agreement, the defendant promises to plead guilty to certain counts in exchange for a prosecutor's promise to help the defendant in some way, such as by moving to dismiss other counts that otherwise would have been litigated at the defendant's trial. ${ }^{36} \mathrm{Al}-$ though the court is prohibited from participating in plea negotia-

\footnotetext{
${ }^{35}$ See Part III for a discussion of whether resentencing comports with statutory and constitutional doctrine.

${ }^{36}$ Other types of promises might be made by defendant and prosecutor. The defendant might promise to assist the prosecutor by testifying against another defendant. The prosecutor might promise to make a certain sentencing recommendation to the judge, agree not to oppose the defendant's request for a particular sentence, or agree that a specific sentence is appropriate for the disposition of the case. Review of Criminal Procedure, 84 Georgetown L J at 1040 (cited in note 7).
} 
tions,$^{37}$ the court decides whether to accept or reject the plea agreement. ${ }^{38} \mathrm{~A}$ plea agreement is governed by the law of contracts, ${ }^{39}$ and if the defendant breaches the plea agreement, the government is free to reprosecute the defendant. ${ }^{40}$

Plea agreements play a pervasive role in our criminal justice system. Nearly 90 percent of all federal criminal cases involve guilty pleas and many of these cases involve some form of plea agreement. ${ }^{41}$ Because plea agreements are so prevalent, it is important to devise an appropriate method of interpreting plea agreements after a supervening change in the law.

\section{B. Incorrect Applications of Contract Doctrine}

Some courts have incorrectly applied contract law in cases involving collateral attacks based on changes in a substantive criminal law. Errors include treating the defendant's failure to appeal as a procedural default and treating the collateral attack as a breach of contract.

\section{Failure to appeal as a procedural default.}

The first misapplication of contract law treats the defendant's failure to appeal his "pleaded" conviction as a procedural default of the right to later collaterally attack the conviction in

${ }^{3}$ FRCrP 11(e)(1).

${ }^{33}$ FRCrP 11(e)(3)-(4). The court must determine that the plea was voluntary, ensure that there is a factual basis for the plea, and address the defendant in open court before accepting the plea agreement. FRCrP 11(f)-(g).

${ }^{3}$ See Review of Criminal Procedure, 84 Georgetown L $J$ at 1041 \& $n 1341$ (cited in note 7) (collecting cases).

6 Ricketts $v$ Adamson, 483 US 1, 9-12 (1987) (agreement void and government allowed to reinstate original charges when defendant breached promise to testify at codefendant's trial). In Ricketts, the defendant had promised in the plea agreement to testify against certain codefendants. Id at 3 . The defendant subsequently refused to testify, asserting that his obligation to testify terminated upon his sentencing. Id at 4 . The state court construed the defendant's failure to testify as a breach, and the United States Supreme Court deferred to the state court's determination of this issue. Id at 5-6 $\mathrm{n} \mathrm{3}$. Thus, while Ricketts provides guidance on the legally permissible consequences of a breach, it does not suggest how to discern whether a breach has occurred.

${ }^{41}$ USSG, Ch 1, Pt A(4)(c). For a scholarly debate over the merits of plea agreements, compare Frank H. Easterbrook, Plea Bargaining as Compromise, 101 Yale L J 1969, 1975 (1992) (defending plea bargaining as a less costly and more efficient solution than trial), with Stephen J. Schulhofer, Plea Bargaining as Disaster, 101 Yale L J 1979, 1998 (1992) (criticizing plea agreements as plagued by an absence of monitoring mechanisms, a failure to internalize the social effects of punishment, and a divergence of interests between attorneys and their principals). For a critical discussion of the history of plea bargaining, see Albert W. Alschuler, Plea Bargaining and Its History, 79 Colum L Rev 1 (1979) (concluding that plea bargaining was essentially unknown during most of the history of the common law). 
light of a subsequent change in the law. In Bousley $v$ Brooks, ${ }^{42}$ the Eighth Circuit held that the defendant had procedurally defaulted his $\S 2255$ motion by failing to challenge on appeal the pre-Bailey "mere possession" standard that the parties had relied on during plea agreement negotiations. ${ }^{43}$ Because of this earlier procedural default, the court did not reach the merits of the defendant's motion to vacate his $\S 924(\mathrm{c})(1)$ conviction. Thus, the court did not reach the propriety of allowing the government to resentence on the remaining counts or to reinstate the counts it had dismissed pursuant to the plea agreement. The court reasoned that the plea agreement had involved a carefully balanced negotiation leading to the defendant's guilty plea in exchange for the right to contest at sentencing the amount of narcotics for which he would be held accountable. ${ }^{44}$ Further, the sentencing court had "meticulously advised" the defendant that a guilty plea would foreclose an appeal of his conviction and waive the defendant's right to a jury trial; hence, the defendant's plea was not involuntary. ${ }^{45}$ The court therefore held that the defendant had implicitly waived his right to collaterally attack the $\S 924(c)(1)$ conviction that resulted from this evenly negotiated plea agreement. ${ }^{46}$

The Eighth Circuit's approach is incorrect because the court neglected to consider the contract doctrine of impossibility of performance. This doctrine has been applied in some post-Bailey cases. ${ }^{47}$ In ordinary contract cases, this doctrine discharges a promisor from his obligation to perform when that "performance is made impracticable, without his fault, by the occurrence of an event the non-occurrence of which was a basic assumption on which the contract was made. ${ }^{348}$ In this case, the unexpected shift in interpretation of $\S 924(c)(1)$ provides both "cause" for failing to appeal and impracticability of performance of the $\S 924(c)(1)$ sentence insofar as one cannot lawfully "perform" a sentence for conduct no longer deemed criminal.

97 F3d 284 (8th Cir 1996).

4 Id at 287 .

4 Id at 287-88.

45 Id at 288 .

4 Id at 289. The court also observed, however, that a defendant's guilty plea and failure to appeal would not have constituted a procedural default of his right to collaterally attack his conviction upon a showing of cause and prejudice. Id at 288.

${ }^{47}$ See, for example, Rodriguez $v$ United States, 933 F Supp 279, 282-83 (S D NY 1996); United States $v$ Gaither, 926 F Supp 50, 52 (M D Pa 1996).

${ }^{4}$ Restatement (Second) of Contracts $\$ 261$ (1979). See also UCC \& 2-615(a) (same); Restatement (Second) of Contracts at $\$ 264$ (discharge of obligation permissible when performance made impracticable by a supervening governmental regulation or order). 
However, the impossibility doctrine does not always discharge the promisor from his obligation to perform, leaving the loss where it falls. Rather, it is often necessary to adjust the rights of the parties "on such terms as justice requires." ${ }^{\text {"9 }}$ But because there are two competing interests implicated in this context, it is not clear what justice requires. Society has an interest in punishing criminals proportionately for their culpable conduct. On the other hand, the defendant has an interest in avoiding an upward adjustment of the sentence that remains after his successful collateral attack. The impossibility doctrine neither indicates which of these interests should prevail nor suggests a way to balance them.

\section{Collateral attack as a breach of the plea agreement.}

A second erroneous application of contract law views a defendant's collateral attack as a breach of the plea agreement. In United States $v$ Viera, ${ }^{50}$ the defendant had executed a plea agreement whereby he agreed to plead guilty to a $\S 924(\mathrm{c})(1)$ count in exchange for the government's dismissal of other counts. ${ }^{51}$ The agreement was silent as to whether the defendant could appeal or collaterally attack his conviction or sentence. ${ }^{52}$ The defendant began serving his five-year prison sentence, and after Bailey was decided, the defendant made a $\S 2255$ motion to vacate his $\$ 924(c)(1)$ conviction. ${ }^{53}$ The court agreed with the defendant that the facts described in the plea agreement did not support a $\$ 924(\mathrm{c})(1)$ conviction in light of Bailey. ${ }^{54}$

However, the court characterized the defendant's motion as a breach of his plea agreement..$^{55}$ Purporting to interpret the plea agreement under principles of contract law, the court held that the defendant had breached an implicit term in the agreement

${ }^{43}$ Restatement (Second) of Contracts $\$ 272(2)$ (1979). See generally John D. Calamari and Joseph M. Perillo, The Law of Contracts § 13-23 at 577-79 (West 3d ed 1987).

* 931 F Supp 1224 (M D Pa 1996).

${ }^{11}$ Id at 1226.

${ }^{62}$ Id. The agreement contained a merger clause stating that there were no other written or oral agreements and that no other promises had been made to the defendant. Id. A merger clause has been defined as "a clause in the instrument that states that the writing is a final expression of all the terms agreed upon and is a complete and exclusive statement of those terms." Calamari and Perillo, The Law of Contracts $\$ \$ 3-6$ at 156 (citation omitted) (cited in note 49).

${ }^{53}$ Viera, 931 F Supp at 1226.

5 Id at 1227. The defendant had admitted that he kept both a gun and cocaine intended for sale in his bedroom, which would not violate the "use" statute under the Court's interpretation in Bailey. Viera, 931 F Supp at 1226-27.

Es Viera, 931 F Supp at 1228. 
central to the parties' reasonable expectations-that the defendant would neither appeal nor collaterally attack his conviction. ${ }^{56}$

The Viera court erred in its application of contract law principles. ${ }^{67}$ Although the parties may have reasonably expected that the defendant would not appeal or collaterally attack the conviction in the absence of an unforeseen change in the law, the law did change in an unexpected manner. Precedent had been nearly uniform prior to Bailey, ${ }^{58}$ and thus it is unlikely that either the prosecutor or the defendant was cognizant of a risk that the law would change. Thus, the "non-occurrence" of a change in the law was an unspoken assumption of the plea agreement and the impossibility doctrine should have applied to excuse the defendant from serving the remainder of his $\S 924(c)(1)$ sentence. However, as noted above, the impossibility doctrine gives little guidance at the remedial stage, suggesting obliquely that the rights and duties of the parties should be adjusted "on such terms as justice requires. ${ }^{n 9}$

\section{PERMISSIBILITY OF RESENTENCING ON REMAINING VALID COUNTS}

Contract law poses no obstacle to the resentencing option and leaves the reinstatement option on the table so long as it comports with "justice." Yet principles of contract law do not pose the only hurdles to the resentencing and reinstatement remedies. This Part investigates possible jurisdictional, double jeopardy, and due process challenges to the adjustment mechanism of resentencing on remaining counts. ${ }^{60}$ Obstacles to the reinstatement mechanism will be considered in Part IV.

\section{A. Jurisdiction}

A court must have express statutory authorization to modify an imposed term of imprisonment. ${ }^{61}$ Although $\S 2255$ provides authorization to vacate the challenged count, jurisdiction over

\footnotetext{
${ }^{55}$ Id.

${ }^{57}$ The court held that the proper remedy for defendant's breach would be for the government to be allowed to reinstate the original indictment. Id at 1229. As Part IV argues, this is the correct result. Thus, the Viera court erred in its approach, but not in its ultimate resolution.

${ }^{\infty}$ See note 19.

${ }^{69}$ Restatement (Second) of Contracts § 272(2).

${ }^{\infty}$ While the analysis continues to focus on convictions resulting from a plea agreement, the reader should note that this discussion of resentencing applies equally in the case of convictions resulting from a trial.

${ }^{61} 18$ USC \& 3582(c) (1994).
} 
the remaining counts is less clear. ${ }^{62}$ To resentence on those counts, the court must have jurisdiction over them, because resentencing is an act of the court.

Much of the uncertainty regarding courts' jurisdiction over the remaining counts stems from disagreement about the meaning of "sentence" in $\$ 2255 .{ }^{63}$ Some courts permit resentencing on the ground that the interdependent relationship between the $\S 924(c)(1)$ count and the other counts created a "sentencing package" such that the defendant received one comprehensive sentence for all of his counts. ${ }^{64}$ Other courts refuse to permit resentencing on the ground that a multi-count conviction produces independent sentences for each count. ${ }^{65}$ Thus, the definition of "sentence" is important because, if the defendant receives one aggregate sentence on all of his counts, then by challenging one count he has challenged that aggregate sentence and may have placed the entire package within the court's jurisdiction. ${ }^{66}$ On the other hand, if the defendant's sentences are properly viewed in isolation, then the defendant has only placed the sentence he is challenging within the court's jurisdiction.

${ }^{62}$ The relevant language of $\S 2255$ was enacted in 1948, see 62 Stat 967-68 (1948), before the enactment of $\$ 3582$, see Sentencing Reform Act of 1984, Pub L No 98-473, 98 Stat 1998. Because nothing in the text or legislative history of 18 USC $\$ 3582(c)$ suggests that Congress intended to limit district courts' jurisdiction under $\$ 2255$, an argument can be made that the former statute is irrelevant in the interpretation of the latter. Gordils $v$ United States, 943 F Supp 346, 351 (S D NY 1996). However, the Gordils court did not rely on this rationale in deciding that it had jurisdiction to resentence the movant. Id at 352-53.

${ }^{\natural}$ Other jurisdictional issues arise from the language of $\$ 2255$. See Mixon $v$ United States, 926 F Supp 178, 181 (S D Ala 1996) (finding jurisdiction in language authorizing the court to "correct the sentence"). Compare Warner v United States, 926 F Supp 1387, 1398 ( $E$ D Ark 1996) (holding that resentencing is unavailable to the government because relief under $\$ 2255$ is available only to a "prisoner in custody"), with United States $v$ Rowland, 1996 US Dist LEXIS 13377, *4 n 4 (E D Pa) (holding that the court can take into account the government's resentencing request).

'See, for example, Woodhouse v United States, 934 F Supp 1008, 1012-13 (C D IIl 1996); Smith v United States, 103 F3d 531, 533 (7th Cir 1996). The Seventh Circuit in Smith was the first circuit court of appeals to consider the permissibility of resentencing.

${ }^{e 5}$ See, for example, Warner, 926 F Supp at 1397; Rodriguez $v$ United States, 933 F Supp 279, 284 (S D NY 1996).

${ }_{65}$ Some courts hold that the interdependence of the sentences gives the sentencing court the "inherent authority" to adjust unchallenged counts. See, for example, Pedretti $v$ United States, 1996 US Dist LEXIS 6315, *5 (N D NY). 18 USC $\$ 3582$, the statute that requires express statutory authorization before a court can modify a term of imprisonment, dispels any notion that a court can have "inherent authority" to resentence on unchallenged counts. Nonetheless, interdependence of the counts does support the view that when a defendant challenges one count, he brings the entire sentencing package before the court. See Merritt $v$ United States, 930 F Supp 1109, 1113-14 (E D NC 1996). 
Courts permitting resentencing hold that a multi-count conviction involving a $\$ 924(c)(1)$ count and an additional count or counts produce an interdependent sentencing package. This is so because the court could not have initially sentenced the defendant both on a $\S 924(c)(1)$ conviction and enhanced the defendant's other sentences under $\S 2 \mathrm{D} 1.1(\mathrm{~b})(1)$ of the Guidelines.$^{67} \mathrm{In}$ other words, the decision to sentence on the $\$ 924(c)(1)$ conviction affected the availability of the $\S 2 D 1.1(b)(1)$ enhancement, and thus created an interdependence between the sentence on the $\S 924$ (c)(1) count and the sentences on the other counts. The fact that the prosecutor either dropped certain charges or recommended more lenient sentencing in reliance on the defendant's $\S 924(c)(1)$ guilty plea also suggests interdependence.

However, one court has pointed out that the notion of an interdependent sentencing package developed in cases where the defendant successfully challenged one of his counts on direct appeal and was resentenced on the remaining counts on remand, ${ }^{68}$ not in cases involving a successful collateral attack. ${ }^{69}$ The two contexts are not interchangeable, because they rest on different statutory grants of jurisdiction. ${ }^{70}$ Thus, despite the interdependence between a $\$ 924(c)(1)$ count and other counts, resentencing may be deemed inappropriate due to the "narrow scope of review" under $\S 2255 .^{71}$

${ }^{6}$ Merritt, 930 F Supp at 1114; Woodhouse, 934 F Supp at 1013. See Part I.A. The Seventh Circuit in Smith addressed the issue of whether the sentencing package principle, which developed before the Guidelines came on the scene, remains a viable concept under the Guidelines. The Seventh Circuit concluded that, at least in the case of the "either-or relationship" that exists between $\$ 924(\mathrm{c})(1)$ and the $\S 2 \mathrm{D} 1.1(\mathrm{~b})(1)$ enhancement, the sentencing package principle remains viable. Smith, $103 \mathrm{~F} 3 \mathrm{~d}$ at 534.

${ }^{6}$ See, for example, United States $v$ Pimienta-Redondo, 874 F2d 9, 17 (1st Cir 1989); United States $v$ Shue, 825 F2d 1111, 1116 (7th Cir 1987).

${ }^{\infty}$ Rodriguez, 933 F Supp at 284-85.

${ }^{70}$ The statutory grant of jurisdiction present in cases on remand after a direct appeal is 28 USC \$ 2106 (1994), which permits "[t]he Supreme Court or any other court of appellate jurisdiction... [to] remand the cause and direct the entry of such appropriate judgment, decree, or order, or require such further proceedings to be had as may be just under the circumstances." See Rodriguez, 933 F Supp at 285.

${ }^{71}$ Rodriguez, 933 F Supp at 284, quoting United States $v$ Rosen, 764 F2d 763, 766 (11th Cir 1985) ("The narrow scope of review on a collateral attack is almost jurisdictional in nature. The court has power only over what is brought before it."). See also Beal v United States, 924 F Supp 913, 917 (D Minn 1996) (distinguishing $§ 2255$ proceedings from cases in which resentencing occurs after vacatur and retrial for the same offense). Compare also cases where a defendant challenges one of his sentences under FRCrP 35, a context in which some courts have held that jurisdiction only extends to the illegal portion of the challenged "sentence." See United States v Henry, 709 F2d 298, 306-13 (5th Cir 1983) (en banc) (plurality opinion) (analyzing the history of Rule 35, the text of Rule 35, and the meaning of the word "sentence"); United States $v$ Minor, 846 F2d 1184, 1188-89 (9th Cir 1988) (following Henry). But see United States v Bentley, 850 F2d 327, 329 (7th 
Neither side's position on the proper definitional scope of a "sentence" clearly resolves whether a court can permissibly enhance the defendant's sentence(s) on remaining valid counts. Although some precedent supports relying on the "sentencing package" principle to find jurisdiction to resentence, that precedent developed in the context of a remand after direct appeal, a context distinguishable insofar as it derives from a different statute and concerns a different type of adjudicatory proceeding.

\section{B. Double Jeopardy}

Even if the court has jurisdiction to resentence the defendant on the remaining valid counts, the gap in time between the initial sentencing and the later resentencing after a successful $\S 2255$ motion raises double jeopardy concerns. ${ }^{72}$ According to the Supreme Court, "the Double Jeopardy Clause protects against three distinct abuses: a second prosecution for the same offense after acquittal; a second prosecution for the same offense after conviction; and multiple punishments for the same offense."73 The resentencing of a defendant after a successful $\S 2255$ motion raises concerns about the third of these abuses. While technically two or more punishments doled out at different times could be considered "multiple," the Supreme Court's double jeopardy jurisprudence suggests otherwise-a successive punishment is not "multiple" unless the defendant has acquired a legitimate "expectation of finality in the original sentence." Thus, a defendant who succeeds in his effort to set his original sentence aside and receives a higher sentence after retrial cannot claim a double jeopardy violation because one has no legitimate "expectation of finality" in a sentence that one seeks to set aside. ${ }^{75}$

Because a defendant can maintain no legitimate "expectation of finality" in a sentence he attacks, the availability of a sentence enhancement will turn on how broadly one defines "sentence."

Cir 1988) (holding that Rule 35 allows the court to revise the entire sentencing scheme).

${ }_{72}$ The Double Jeopardy Clause provides: "No person shall ... be subject for the same offence to be twice put in jeopardy of life or limb." US Const, Amend V, cl 2.

${ }^{73}$ United States $v$ Halper, 490 US 435, 440 (1989), citing North Carolina v Pearce, 395 US 711, 717 (1969).

${ }^{74}$ United States v DiFrancesco, 449 US 117, 139 (1980). For an analysis of DiFrancesco and the underlying values of the Double Jeopardy Clause, see Peter Westen, The Three Faces of Double Jeopardy: Reflections on Government Appeals of Criminal Sentences, 78 Mich L Rev 1001 (1980).

${ }^{75}$ See DiFrancesco, 449 US at 135-36, discussing Pearce, 395 US 711 (Pearce dealt with resentencing after retrial, while DiFrancesco involved a new sentence after an appeal by the government from a court's sentencing determination.). 
Here, as with the jurisdictional issue ${ }^{76}$ the courts permitting resentencing hold that a defendant who challenges one of several interdependent sentences (or underlying convictions) has, in effect, challenged the entire "sentencing package" and thus cannot maintain a legitimate expectation of finality in any discrete portion of the sentencing package, even a portion that he has not attacked. ${ }^{77}$

An alternative rationale for holding that resentencing does not violate the Double Jeopardy Clause derives from the view that failure to enhance the remaining counts after vacating the § 924(c)(1) sentence would effectively leave in place an incorrect sentence. Because $\S 2 \mathrm{D} 1.1(\mathrm{~b})(1)$ mandates an enhancement when a firearm was possessed unless a $\S 924(c)(1)$ violation is charged, an incorrect sentence remains when the $\S 924(c)(1)$ count is removed..$^{78}$ Because the Supreme Court has held that the Double Jeopardy Clause is not violated when a court resentences a defendant to correct an illegal sentence, ${ }^{79}$ imposing the $\S 2 \mathrm{D} 1.1(\mathrm{~b})(1)$ enhancement would be acceptable.

In contrast, the courts finding resentencing impermissible reason that sentences are independent in the context of a $\$ 2255$ motion and thus define "sentence" more narrowly. ${ }^{80}$ One of these courts acknowledges that, in the direct appeal context, the defendant may not have acquired a legitimate expectation of finality in his unchallenged sentences (or underlying convictions) by the time they are enhanced on remand after an appeal. ${ }^{81}$ However, this court distinguishes a $\S 2255$ motion from a direct appeal on the ground that the former's greater temporal distance from the original sentencing and more narrow jurisdictional scope enable the defendant to form a legitimate expectation of finality in the unchallenged counts. ${ }^{82}$

${ }^{76}$ See Part III.A.

7 Merritt $v$ United States, 930 F Supp 1109, 1115 (E D NC 1996); Mixon v United States, 926 F Supp 178, 180-81 (S D Ala 1996); Mayes v United States, 937 F Supp 659, 661 (E D Mich 1996); Woodhouse v United States, 934 F Supp 1008, 1014 (C D IIl 1996). These courts rely on direct appeal cases for the "sentencing package" theory. See note 68 and accompanying text.

${ }^{78}$ See Part I.A.

${ }^{79}$ Bozza v United States, 330 US 160, 166-67 (1947).

Warner $v$ United States, 926 F Supp 1387, 1393 (E D Ark 1996); Dossett v United States, 931 F Supp 686, 687-88 (D SD 1996).

${ }^{81}$ Warner, 926 F Supp at 1393.

62 Warner, $926 \mathrm{~F}$ Supp at 1393-94 \& $\mathrm{n} 11$. Here again it is apparent that the jurisdiction and double jeopardy issues are interrelated. 
The view that resentencing does not violate the Double Jeopardy Clause is slightly more persuasive. ${ }^{83}$ Although the issue whether a defendant has acquired a legitimate expectation of finality $^{84}$ in his sentence is circular to some extent, there are several reasons why a defendant might not have an expectation of finality in any discrete portion of his aggregate sentence.

First, the defendant could be charged with notice that the $\S 2 \mathrm{D} 1.1(\mathrm{~b})(1)$ enhancement was not applied originally due to the presence of the $\S 924(c)(1)$ conviction and therefore that an interdependent relationship exists between the $\$ 924(\mathrm{c})(1)$ count and the other counts. The defendant might also be charged with notice of the cases holding that enhancing sentences on remaining counts on remand after a direct appeal does not violate the Double Jeopardy Clause. In United States $v$ DiFrancesco, ${ }^{85}$ the Supreme Court held that the defendant lacked an expectation of finality in a sentencing judgment from which the government appealed, reasoning that the defendant should be charged with notice of a statute that allowed the government to appeal from the lower court's sentencing determination..$^{86}$ There is no reason why a post-Bailey $\S 2255$ defendant could not similarly be charged with notice of the Guidelines. Furthermore, it is the defendant, not the government, who is instigating review of his sentence. Thus, the defendant seems to have even less of a legitimate expectation of finality in his sentence than did the defendant in DiFrancesco.

Yet this reasoning is not iron-clad. The statute at issue in DiFrancesco ${ }^{87}$ expressly stated that the government could appeal from the district court's sentencing determination, and that is what the government did. However, neither the Guidelines, nor

\footnotetext{
${ }^{83}$ One factual situation-where the defendant has completed serving the sentence on the count that the government requests the court to enhance-has provoked considerable confusion among the courts, leading to diverse conclusions in dicta even among those courts permitting resentencing. Thus, some courts hold (or state in dicta) that by virtue of having completed the sentences on the counts that remain after the $\$ 2255$ motion, the defendant has acquired a legitimate expectation of finality in those portions of his sentence that were lawful at the time that service of the sentences was completed, and thus it would violate the defendant's double jeopardy rights to resentence him on those counts. See Warner, 926 F Supp at 1394-95 (holding); United States $v$ Tolson, 935 F Supp 17, 21 (D DC 1996) (dicta). Other courts hold that even a defendant who completes service of a then-lawful sentence can receive an enhancement on that sentence after a successful $\S 2255$ motion. See Merritt, 930 F Supp at 1114-15; Thayer v United States, 937 F Supp 662, 666-67 (E D Mich 1996).

${ }^{84}$ United States $v$ DiFrancesco, 449 US 117, 139 (1980).

Es 449 US 117 (1980).

${ }^{85}$ Id at 139.

"77 USC \& 3576; see DiFrancesco, 449 US at 138.
} 
any statute, nor any uniform body of precedent states that the government may enhance remaining sentences or reinstate the original indictment after a successful collateral attack.

\section{Due Process}

Resentencing a successful $\S 2255$ defendant on his remaining counts might violate the defendant's due process rights if doing so would be fundamentally unfair. The Fourth Circuit, analyzing the double jeopardy and due process protections available to a previously sentenced defendant, noted that the DiFrancesco Court had not clearly set forth the constitutional protections against enhancement of the defendant's sentence after the sentence had commenced. ${ }^{88}$ To fill this gap, the Fourth Circuit set forth a new protective standard grounded in the Due Process Clause: "due process may . . . be denied when a sentence is enhanced after the defendant has served so much of his sentence that his expectations as to its finality have crystallized and it would be fundamentally unfair to defeat them."

This due process test is virtually identical to the double jeopardy analysis of whether the defendant had an "expectation of finality" in his sentence..$^{90}$ Courts permitting resentencing generally hold that a defendant who challenges part of an interdependent sentencing package lacks a "crystallized" expectation of finality in any component of the package. ${ }^{11}$ In contrast, one court held that by the time the defendant made his $\S 2255$ motion, such a substantial period of time had passed that the defendant's expectations as to his sentence's finality had crystallized, so that it would be fundamentally unfair to resentence him on the re-

${ }^{8}$ United States $v$ Lundien, 769 F2d 981, 985 (4th Cir 1985). A court might also find a due process violation under two other scenarios. First, a court might find that a prosecutor's motion to resentence constitutes prosecutorial vindictiveness. See North Carolina $v$ Pearce, 395 US 711, 725 (1969) ('Due process of law ... requires that vindictiveness against a defendant for having successfully attacked his first conviction must play no part in the sentence he receives after a new trial."). Neither the courts permitting resentencing nor the courts that forbid resentencing have considered the implications of the Pearce doctrine. Second, in a case where the defendant had already served his sentence and been released, resentencing would re-deprive the defendant of his liberty, arguably without adequate protection and thus in violation of the Due Process Clause. In Woodhouse, the court held that further imprisonment of the defendant under these circumstances did not violate the Due Process Clause. Woodhouse, 934 F Supp at 1015.

${ }^{29}$ Lundien, $769 \mathrm{~F} 2 \mathrm{~d}$ at 987 . In Lundien, the government moved to amend the defendant's sentence five days after the defendant commenced serving it. Id. The court held that the defendant's expectations had not crystallized within that brief five-day period. Id.

${ }^{9}$ See Part III.B.

${ }^{91}$ See, for example, Thayer, 937 F Supp at 667; Merritt, 930 F Supp at 1115. 
maining counts. ${ }^{92}$ One court splits the difference on this issue, allowing for the two-point $\S 2 \mathrm{D} 1.1(\mathrm{~b})(1)$ enhancement but using its downward departure power to subtract one point because the defendant had served a significant portion of his original sentence. ${ }^{93}$

For the same reasons set forth in Part III.B of this Comment, discussing the similar double jeopardy test, the Fourth Circuit's test does not clearly determine whether resentencing a defendant on remaining counts violates the fundamental fairness aspect of the Due Process Clause.

Looking back at the analysis of the resentencing remedy in light of statutory and constitutional hurdles, one observes several reasonably persuasive arguments favoring the permissibility of resentencing. Admittedly, however, intelligent arguments against the permissibility of the resentencing remedy also exist. Unfortunately, the doctrine does not point to a clear answer. In Part V, some first principles will be introduced into the analysis to help inform the legal doctrine. But first it is necessary to consider the statutory and constitutional hurdles to the alternate remedy of reinstating the original indictment.

\section{PERMISSIBILITY OF REINSTATING THE ORIGINAL INDICTMENT}

The government has made far fewer attempts to use the reinstatement remedy than the resentencing remedy. ${ }^{94}$ As a result, the case law on the permissibility of the reinstatement remedy is somewhat sparse. Nonetheless, three main obstacles facing the reinstatement remedy can be identified: the statute of limitations, the Double Jeopardy Clause, and the Due Process Clause.

\footnotetext{
92 Warner, 926 F Supp at 1395-96.

${ }^{* 3}$ United States $v$ Ray, 1996 US Dist LEXIS 18091, *13 (D DC). Under the Guidelines, a judge may depart downward from the applicable Guidelines range if the judge finds that the case includes a mitigating circumstance that the Sentencing Commission did not adequately consider. See USSG § 5K2.0, policy statement (quoting 18 USC § 3553(b) (1994)). For other circumstances in which the judge may depart downward, see generally Review of Criminal Procedure, 84 Georgetown L J at 1279-89 (cited in note 7).

${ }^{2}$ In fact, in situations where the plea agreement produced more than a lone \$ 924(c)(1) count making both resentencing and reinstatement feasible adjustment alternatives, the government generally prefers the resentencing remedy and only once preferred the reinstatement remedy. See Rodriguez $v$ United States, 933 F Supp 279, 280 (S D NY 1996) (government sought restoration of the original indictment). Part V offers an explanation of why the government seems to prefer the resentencing remedy to the reinstatement remedy when both are available.
} 


\section{A. The Statute of Limitations for Criminal Prosecutions}

To see the importance of the statute of limitations in this context, ${ }^{95}$ recall the Bailey timeline. A defendant may have pled guilty to $\S 924(c)(1)$ six years before the Supreme Court decided Bailey. After the defendant's collateral attack of his $\S 924(c)(1)$ count succeeds, seven years may have elapsed since the date of the offense. Because the statute of limitations for noncapital criminal offenses is five years, the defendant can argue that re'nstatement of the original indictment is barred. Thus, depending upon whether or not a court is willing to toll the statute of limitations, the reinstatement remedy could be constrained to those defendants whose successful collateral attacks occur within five years of the date of the offense.

In United States $v$ Gaither, the court held that, under circumstances like those described above, the statute of limitations barred reinstatement of the original indictment. ${ }^{96}$ The court reasoned that the purpose of the statute of limitations is to protect accused persons "from having to defend themselves against charges when the basic facts may have become obscured by the passage of time." 97 The court declined to accept the government's argument that, because it proceeded with diligence and was not responsible for the lapse of five years, the statute of limitations should be tolled. ${ }^{98}$ The court did observe that a refusal to toll the statute of limitations might encourage defendants to wait strategically until five years had expired before bringing collateral attacks. But the court found that concern not present in the scenario presented by Bailey because an "abrupt change in the law ... cannot be anticipated by defendants."

The opposite conclusion was reached in United States $v$ Viera ${ }^{100}$ in which the court tolled the statute of limitations to allow the prosecutor to reinstate the original indictment. ${ }^{101}$ The court reasoned that the defendant's collateral attack upset what the government reasonably understood to be a final disposition of

95 18 USC $\S 3282$ (1994) is the general statute of limitations for noncapital criminal offenses. It requires that the indictment be "found" within five years of the date of the offense. Id. The statute of limitations for criminal prosecutions is relevant for reinstatement but not for resentencing. This is because the resentencing remedy involves previously entered convictions rather than unproven counts.

${ }_{96} 926$ F Supp 50, 53 (M D Pa 1996).

${ }^{97}$ Id.

${ }^{28} \mathrm{Id}$.

$\because$ Id at 54.

${ }^{100} 931$ F Supp 1224 (M D Pa 1996).

${ }^{101} \mathrm{Id}$ at 1231. 
a criminal matter. ${ }^{102}$ The court also expressed concern that to fail to toll the statute of limitations would confer a "windfall" on the defendant. ${ }^{103}$ The court disagreed with the Gaither court's assertion that courts are bound to apply the statute of limitations because Congress did not enact a good faith exception, and provided several examples where courts had tolled the statute of limitations. ${ }^{104}$

In evaluating the rationales offered by these two courts in support of their conclusions, one must concede that courts have tolled statutes of limitations in other contexts. For example, courts have permitted indictments to be timely filed under seal for valid prosecutorial reasons and then made public after the limitations period had expired even though this technically gives the defendant notice after the limitations period. ${ }^{105}$ In such a situation, the defendant certainly is at a disadvantage in marshaling fresh evidence in his favor, and yet the prosecutorial interest in secrecy was held to outweigh the defendant's interest. Similarly, in the post-Bailey cases, tolling the statute of limitations would hinder the defendant's ability to present a defense but arguably would be justified by the government's interest in prosecuting the defendant anew and the government's lack of fault for the delay. ${ }^{106}$

It is true that the primary purpose of the statute of limitations is to protect defendants from having to defend themselves

\footnotetext{
${ }^{102}$ Id at 1230-31.

${ }^{103} \mathrm{Id}$ at 1231. Part V of this Comment fleshes out the windfall concern in greater detail.

${ }^{12}$ Viera, 931 F Supp at 1231.

${ }^{105}$ See United States $v$ Levine, 658 F2d 113, 120-21 n 9 (3d Cir 1981); United States v Muse, 633 F2d 1041, 1042 (2d Cir 1980) (en banc); United States $v$ Michael, 180 F2d 55, 56-57 (3d Cir 1949).

${ }^{10 s}$ However, the Second Circuit recently offered the first court of appeals decision concerning a closely analogous issue and concluded that the statute of limitations cannot be tolled in the case of a defendant who withdraws his guilty plea in light of a change in the law. United States $v$ Podde, 1997 US App LEXIS 1593 (2d Cir) (involving plea to lesser included offense withdrawn by defendant after subsequent Supreme Court decision requiring a higher standard of mental state for that offense, followed by government's attempt to reinstate the original charges after the statute of limitations had run). The court noted that one rationale for the statute of limitations, encouraging diligence by the government, was not threatened in such a pattern because the government could not have acted more diligently in light of the unforeseen change in the law and subsequent plea withdrawal. However, the court characterized that rationale of the statute of limitations as subsidiary to the principal rationale of protecting defendants from having to defend against stale claims. Id at *17. The court also cited a Supreme Court directive that "criminal limitations statutes are to be liberally interpreted in favor of repose." Id at *18, quoting Toussie v United States, 397 US 112, 114-15 (1970).
} 
from charges resting on facts obscured by time.$^{107}$ However, there is no reason why a court could not weigh this interest of the defendant against the government's interest in prosecuting the defendant anew.

\section{B. Double Jeopardy}

As noted above, the Double Jeopardy Clause protects defendants against a number of different abuses. ${ }^{108}$ The reinstatement remedy implicates two of these abuses. First, the protection against multiple punishment for the same offense, discussed in relation to the resentencing remedy in Part III.B, applies similarly here. Only one court has addressed this aspect of double jeopardy protection, holding that the reinstatement remedy does not violate the Double Jeopardy Clause. ${ }^{109}$ Relying on the notion that "[a] defendant has no legitimate expectation of finality in a sentence that he attacks" and also on the notion that a plea agreement produces one aggregate sentence, the court reasoned that the defendant had "open[ed] himself up to conviction and sentence on all counts, including those previously dismissed."110 However, the analysis of courts holding that the resentencing remedy violates the Double Jeopardy Clause suggests that the defendant's collateral attack could also be viewed as an isolated attack on the $\S 924(\mathrm{c})(1)$ sentence. ${ }^{111}$

Second, the reinstatement remedy implicates the protection against a "second prosecution for the same offense after conviction." ${ }^{\text {"12 }}$ No post-Bailey court has yet considered this aspect of double jeopardy protection. In Ricketts $v$ Adamson, ${ }^{113}$ the Supreme Court held that, when the plea agreement expressly provided that the original indictment could be reinstated upon a breach by the defendant, the Double Jeopardy Clause did not preclude the government from reprosecuting a defendant who had breached a condition of his plea agreement. ${ }^{114}$ However, as Part II concluded, a proper contract law analysis demonstrates that the defendant's collateral attack does not constitute a breach. Therefore, Ricketts is inapposite. Nonetheless, rein-

\footnotetext{
${ }^{107}$ See note 97 and accompanying text.

${ }^{103}$ See text accompanying note 73 .

${ }^{109}$ United States v Barron, 940 F Supp 1489, 1496 (D Alaska 1996).

${ }^{110} \mathrm{Id}$, citing Pennsylvania $v$ Goldhammer, 474 US 28 (1985); DiFrancesco, 449 US 117.

${ }^{111}$ See notes 80-81 and accompanying text.

${ }^{112}$ United States $v$ Halper, 490 US 435, 440 (1989).

${ }^{113} 483$ US 1 (1987).

${ }^{114}$ Id at 9.
} 
statement of the original indictment does not violate this aspect of double jeopardy protection. ${ }^{115}$

\section{Due Process}

When the government responds to the defendant's successful collateral attack on his $\S 924$ (c)(1) conviction by reinstating the original indictment, including counts that had been dropped pursuant to the plea agreement, the defendant could argue that this reprosecution violates his due process right to be free from prosecutorial vindictiveness. ${ }^{116}$ In Blackledge $v$ Perry, ${ }^{117}$ the key case recognizing this protection, a state prosecutor responded to a defendant's exercise of his statutory right to appeal ${ }^{118}$ by bringing a more serious charge against him prior to the trial de novo. ${ }^{19}$ The Supreme Court, recognizing that prosecutors had a considerable stake in discouraging convicted misdemeanants from appealing from proceedings in courts not of record, held that this practice violated the Due Process Clause. ${ }^{120}$

Although the statutory right to make a collateral attack in post-Bailey cases is analogous to the statutory right to a trial de novo in Blackledge, the practice challenged in Blackledge is distinguishable from the reinstatement remedy in the post-Bailey scenario. Unlike the Blackledge prosecutor's practice of bringing a more serious charge, the reinstatement remedy does not allow the government to bring more serious charges, but only to reinstate the counts present in the original indictment that were dismissed pursuant to the plea agreement.

However, upon reinstatement of the indictment and consequent plea negotiation (or trial) and sentencing hearing, the government may be constrained to seek a sentence equal to the overall length of the initial sentence with credit given for time served. When the defendant's overall sentence is increased and

${ }^{115}$ See United States $v$ Tateo, 377 US 463, 468 (1964) (holding retrial permissible when conviction declared invalid on collateral attack). See also United States $v$ Podde, 1997 US App LEXIS 1593, *13 (2d Cir) (holding that when the defendant "repudiates" the plea bargain there is no double jeopardy obstacle to retrying him on the charges in the original indictment).

${ }^{116}$ The "fundamental fairness" due process test also potentially applies here. Because the analysis is identical to that for the resentencing remedy in Part III.C (and similarly inconclusive), it is not repeated here.

${ }^{117} 417$ US 21 (1974).

${ }^{118}$ After being convicted of a misdemeanor in the state District Court, the defendant had a statutory right to a trial de novo in the Superior Court. Id at 22.

${ }^{119}$ Id at 23.

${ }^{120}$ Id at 27-29. 
when there is a "reasonable likelihood" that the increased sentence is the product of actual vindictiveness, a rebuttable presumption of vindictiveness is raised. ${ }^{121}$ If the prosecutor lacks any new information logically relevant to sentencing that would justify an increase from the initial aggregate sentence, the prosecutor would not be able to rebut the presumption.

None of these obstacles facing the reinstatement remedy seems insurmountable. With regard to the statute of limitations issue, there are persuasive arguments both ways. ${ }^{122}$ The challenges to the reinstatement remedy raised by the Double Jeopardy and Due Process Clauses do not clearly defeat it, even if they might constrain it. Part $\mathrm{V}$ appeals to some first principles of criminal law for guidance in determining whether resentencing or reinstatement should be permissible.

\section{FIRST PRINCIPLES}

Thus far, this Comment has examined whether two sentence adjustment remedies, resentencing and reinstatement, comport with principles of contract law, the court's jurisdiction, the statute of limitations, the Double Jeopardy Clause, and the Due Process Clause. None of these legal doctrines has provided unequivocal answers. Even if one concludes that resentencing and reinstatement are unquestionably permissible, it does not necessarily follow that the government should make use of them.

This final Part seeks to provide guidance from a broader policy perspective, comparing society's interest in punishing criminals proportionately to their culpable conduct with the defendant's interest in avoiding an upward adjustment of the sentence that remains after his successful collateral attack. ${ }^{123}$ The

${ }^{122}$ Alabama $v$ Smith, 490 US 794, 799 (1989). However, Smith suggests that the Blackledge presumption of prosecutorial vindictiveness might not even apply in the situation of a vacated guilty plea followed by a higher sentence upon conviction after retrial. $S$ mith held that the Pearce presumption of judicial vindictiveness would not apply in this scenario. 490 US at 803 . While the Smith Court did not mention Blackledge, a strong argument can be made that the Smith holding would be carried over to the prosecutorial vindictiveness context. Even if it were, however, the defendant could still claim there was actual vindictiveness on the part of the prosecutor. See 490 US at 803 (declining to reach the question whether the facts supported a finding of actual vindictiveness on the part of the sentencing judge).

${ }^{122}$ Even if one concludes that the statute of limitations cannot be tolled, the reinstatement remedy would be available if the statute of limitations had not yet run.

${ }^{123}$ This approach is suggested by Ronald Dworkin, who argues that judges, in reading legal doctrine, must achieve a "fit" with precedent. In "hard cases," more than one possible reading achieves this "fit." In such cases, Dworkin suggests that the judge should choose the approach that is most justified on grounds of principle. See Ronald Dworkin, 
analysis proceeds in two stages. The first stage examines the merit of the two adjustment mechanisms in the task of "cleaning up the mess" created by Bailey. The second stage contemplates the importance and relevance of post-collateral attack sentence adjustment beyond the post-Bailey context.

\section{A. Cleaning up the Bailey Mess}

The immediate effect of a successful Bailey-inspired collateral attack is to cut the defendant's sentence by five years. ${ }^{124}$ True, the defendant should not be punished for "active employment" of a firearm when the facts did not support such a plea (or verdict). But the five-year reduction undoubtedly leaves some conduct unpunished that the law still deems criminal. ${ }^{125}$ Most obviously, the § 2D1.1(b)(1) enhancement for mere possession of a firearm in relation to a narcotics offense has not yet been applied, for the presence of the now-vacated $\$ 924(c)(1)$ conviction at the initial sentencing precluded the use of the $\S 2 \mathrm{D} 1.1(\mathrm{~b})(1)$ enhancement on the other counts. Further, in the context of a plea agreement in which the prosecutor dismissed certain counts from the indictment in reliance on the defendant's guilty plea to $\S 924(c)(1)$, the prosecutor made a calculated decision to "pin" the culpable conduct covered by those dismissed counts on the $\S 924(c)(1)$ count. In short, failure to adjust the defendant's remaining sentence upward gives the defendant, in the words of several courts, a "windfall." 126

Does this windfall matter? Several theories of punishment suggest that it does. Consider first the theory of cost-justified deterrence, which states that society should deter criminal conduct by imposing a penalty and enforcement mechanism up to the point where the marginal cost of the punishment scheme equals the marginal benefit of avoided criminal conduct. ${ }^{127}$ If the defen-

Taking Rights Seriously 86-88 (Harvard 1978); Ronald Dworkin, Law's Empire 216-28, 244 (Harvard 1986).

${ }^{12 x}$ This is because $\$ 924(c)(1)$ prescribes that its five-year sentence must be served consecutively to any other sentence. 18 USC $\$ 924(c)(1)$.

15 This Comment assumes that the judgment of the Sentencing Commission in specifying a punishment schedule for differing degrees of criminal conduct, and of the prosecutor in deciding what criminal conduct he intends to "pin" on one count by dismissing other counts, reflects society's view of appropriate punishment.

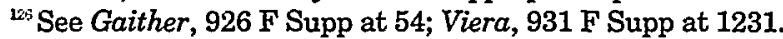

${ }^{227}$ Punishment consists of two components: (1) probability that punishment will be imposed and (2) severity of the punishment. To deter an individual defendant from committing a particular crime, a probability-severity combination must be selected that exceeds the defendant's perceived benefit from committing the crime. If the cost of this punishment is less than the benefit to society from deterring the criminal act, then cost- 
dant's sentence is not adjusted upward, then criminals at large may perceive that society has decided to punish leniently "drugand gun-related" criminal activity. ${ }^{128}$ Thus, if the prosecutor's litigation costs in seeking the upward adjustment are less than the benefits of the increased deterrent effect on (potential) criminals, then cost-justified deterrence favors allowing upward adjustment. ${ }^{129}$ From the standpoint of the "just deserts" theory of punishment, society frowns on letting the defendant off the hook for the conduct of possessing a gun in a drug transaction (and any other conduct covered by counts if such counts were dismissed pursuant to a plea agreement). Thus, both theories favor allowing an upward adjustment of the defendant's sentence.

Concerning the defendant's interest, the post-Bailey defendants can make colorable arguments against upward adjustment based on the Double Jeopardy and Due Process Clauses. And it can be conceded that an upward adjustment of the defendant's remaining sentence is a net increase in the lawfully imposed component of the defendant's sentence, for the § 924(c)(1) conviction should never have occurred in the first place.

However, the defendant's arguments lose force when one considers what "sentence adjustment" term the parties would have agreed to if they had taken into account the risk of a change in the interpretation of $\S 924(\mathrm{c})(1)$ during the plea negotiation. Although this exercise may seem somewhat fanciful, it has been used in other contractual contexts. ${ }^{130}$ Suppose that the risk of a change in the law had been foreseeable because a clear conflict

justified deterrence suggests that the punishment scheme be instituted. See generally Richard A. Posner, Economic Analysis of Law \$ 7.2 at 223-31 (Little, Brown 4th ed 1992).

${ }^{123}$ This deterrence account is based on the assumption that the potential criminals mistakenly perceive a bar on resentencing as a reduction in the penalty that they will receive if convicted. Under a correct analysis by a potential criminal, the disposition of the post-Bailey defendants should have little effect on expected punishment. Rather, Bailey itself lowers the expected penalty for drug activity associated with mere possession of a gun. The $\S 2 D 1.1(b)(1)$ enhancement should still enter the potential criminal's expected punishment, but it does not if the potential criminal mistakenly concludes that because the $\S 2 D 1.1(b)(1)$ enhancement is not being retroactively applied to prisoners who vacate their § 924(c)(1) convictions, it will not be applied in the first instance to his own sentence.

${ }^{120}$ Another factor that enters the cost-justified deterrence calculus is the "specific deterrence" benefit of keeping the post-Bailey defendant off the streets where he might return to criminal activity.

${ }^{130}$ The "would have wanted" theory of filling gaps in contracts states that courts should supply the terms that the parties to a contract would have negotiated, were the costs of negotiating at arm's length sufficiently low. See Frank H. Easterbrook and Daniel R. Fischel, The Economic Structure of Corporate Law 22-35 (Harvard 1991) (discussing the role of corporate law as filling gaps in contracts). 
among the circuits existed concerning the interpretation of $\$ 924(c)(1)$ at the time of the plea negotiation, with some circuits adopting a "mere possession" standard and others adopting an "active employment" standard. Suppose further that the facts demonstrate only "mere possession" of a firearm but support a host of other narcotics counts, a reasonable assumption in many cases. ${ }^{131}$

The prosecutor would then have formulated his plea negotiation strategy taking into account the risk that a five-year sentence associated with a $\$ 924(c)(1)$ count could be vacated. Accordingly, the prosecutor would either insist on a term allowing for sentence adjustment in the event the law did change, or else seek more diverse charge ${ }^{132}$ so that a future vacatur of the $\S 924(c)(1)$ count would only reduce the sentence to the level that the prosecutor would seek to obtain in the absence of any risk of a change in law. The prosecutor might have presented the defendant with a choice of the following options: "(1) In the event of a change in the law, you can move to vacate your $\S 924$ (c)(1) count, but you must agree to allow the government to adjust your sentence upward to reflect unpunished criminal conduct; $;{ }^{133}$ or (2) If you do not agree to this adjustment upon a successful collateral attack, you must plead guilty to a $\S 924(c)(1)$ count and other counts that will make your sentence longer than it would be under option (1)."

Thus, the defendant would choose either a shorter sentence accompanied by a risk of being subjected to an upward sentence adjustment upon a successful collateral attack of the $\S 924(c)(1)$ count, or a longer sentence accompanied by no risk of future sentence adjustment upon a successful collateral attack. Empirical evidence has shown that, relative to the general population, criminals are risk-preferring ${ }^{134}$-all else equal, criminals prefer a

\footnotetext{
${ }^{133}$ See, for example, Thayer v United States, 937 F Supp 662, 663 (E D Mich 1996) (plea agreement to counts of conspiracy to distribute, possession with intent to distribute, use of a firearm in relation to a drug offense, and possession with intent to distribute marijuana, among others).

${ }_{1: 2}$ Diversity of charges is necessary to produce a longer aggregate sentence, for closely related counts will be grouped under the Guidelines. See note 8 and accompanying text.

${ }^{15}$ Such a term would likely be upheld in court. See Ricketts, 483 US at 9 (upholding term in plea agreement that stated that in the event of a breach by the defendant, the government could reinstate the original indictment).

${ }^{1: 4}$ Michael K. Block and Vernon E. Gerety, Some Experimental Evidence on Differences Between Student and Prisoner Reactions to Monetary Penalties and Risk, $24 \mathrm{~J}$ Legal Stud 123, 138 (1995) (conducting experiments and concluding that "there is a significant difference between criminals and the general population in their willingness to accept risk").
} 
higher degree of risk to a longer sentence. Because option (1) offers a shorter sentence with more risk than option (2), most criminal defendants are likely to choose option (1), the option that allows sentence adjustment upon a successful collateral attack. ${ }^{135}$ Therefore, the defendant would have agreed to allow sentence adjustment had the parties taken into account the possibility of a change in the law. ${ }^{136}$

Once one decides that an upward adjustment of the defendant's sentence is legally permissible and normatively desired, it remains to choose an upward adjustment mechanism. The resentencing and reinstatement remedies are not equivalent in cost or effect. Resentencing offers a quick, low-cost method of bumping up the defendant's sentence. First, the parties have already convened in the district court for the $\S 2255$ hearing. Second, application of the $\S 2 \mathrm{D} 1.1(\mathrm{~b})(1)$ enhancement is a sentencing issue and therefore is decided by the judge rather than the jury. Third, the judge will quickly be able to make a finding on whether the defendant possessed a firearm based on the record of the case, given that the pre-Bailey courts based the original $\S 924(c)(1)$ conviction on the conduct of possession of a firearm. The disadvantage of resentencing is that it may not suffice to punish the defendant for conduct that the prosecutor decided to "pin" on the $\S 924(c)(1)$ plea when he dismissed other counts pursuant to the plea agreement.

While reinstatement of the original indictment offers the chance to achieve a closer fit to the punishment that the defendant would have received if convicted in the post-Bailey world, it requires a new plea bargaining session (and if that fails, a new trial) and thus poses considerable litigation costs for the prosecutor. Most likely, this explains why the government has almost uniformly pursued the resentencing remedy rather than the reinstatement remedy in the post-Bailey cases involving plea agreements. Because the prosecutor has the best information on

\footnotetext{
${ }^{135}$ As an empirical matter, the analysis may be more complex. Whether criminals choose (1) or (2) may depend on how risk-averse they are, and how likely a change in the law is.

${ }^{136}$ An argument might be made that the waivable background rule should be that sentence adjustment will not occur. This would act as a penalty default, putting the burden of factoring the risk of a change in the law or successful collateral attack on the prosecutor, for arguably the prosecutor, as a repeat player, has a lower cost than defense counsel of predicting such a change in the law. However, it is not clear that the prosecutor has a better read on trends in the law than the public defender's office. More importantly, the "penalty" of releasing culpable defendants that would result from the proposed penalty default rule would perhaps be too severe in its effects on society.
} 
the litigation costs involved with these different remedies and because the doctrine can plausibly be read to permit both remedies, ${ }^{137}$ courts should allow the prosecutor to choose the remedial strategy.

\section{B. Looking Forward: Beyond the Post-Bailey Context}

The normative thesis of this Comment is that whenever a change in the substantive criminal law precipitates a collateral attack resulting in a sentence that does not reflect all of the defendant's culpable conduct, an upward adjustment should be permitted within the doctrinal limits discussed in Parts III and IV. Thus, this thesis applies when four elements exist: a change in the substantive criminal law, a successful collateral attack, a consequent reduction in sentence, and a remaining sentence that does not reflect all of the defendant's criminal conduct.

The first element, a change in the substantive criminal law, has occurred in the past and undoubtedly will occur in the future. The second element, a successful collateral attack, will likely follow from a change in the law where the prospect of a reduced sentence (the third element) provides the defendant with an incentive to make such a motion. In this respect, the Bailey situation is somewhat unique in that it imposes a mandatory five-year sentence consecutive to sentences on other counts. The more usual treatment of multi-count convictions under the Guidelines is to group counts for the purpose of calculating the offense level where the counts involve substantially the same harm. ${ }^{138}$ However, two other statutes similarly mandate a consecutive sentence ${ }^{139}$ and others might be enacted in the future. A change in the interpretation of any of these statutes might lead to a reduction in sentence. Further, even with grouped counts involving substantially the same harm, the Guidelines prescribe an enhancement in some cases. ${ }^{140} \mathrm{~A}$ vacatur of one of these counts could remove such an enhancement and thus reduce the sentence. The fourth element, a remaining sentence that does not reflect all of the defendant's criminally culpable conduct, would seem to exist in most cases of a conviction resulting from a plea agreement, for the now-vacated count no longer serves as the "vehicle" for punishing the defendant for conduct covered by the previously dismissed counts.

\footnotetext{
${ }^{137}$ See Parts II-IV.

${ }^{1 * 3}$ USSG $\$ \$ 3 D 1.1(a), 3 D 1.2$.

${ }^{\text {w }} 18$ USC $\$ \$ 844(\mathrm{~h}), 929(\mathrm{~b})$ (1994).

${ }^{143}$ USSG § 3D1.4.
} 


\section{CONCLUSION}

Prosecutors seek to allocate their resources to punish defendants for conduct that society finds worthy of punishment. Changes in the substantive criminal law unsettle the punishment scheme that a prosecutor has devised for a particular defendant. A new interpretation of the substantive criminal law, an interpretation favorable to defendants, is a statement that the law no longer considers the defendant's conduct to be as deserving of punishment as it once did. Where such a change was unexpected, the defendant should be given the opportunity to have the court reexamine his sentence. The collateral attack statute rightly provides him with this opportunity.

However, the law should not reward defendants with a windfall. Society has a strong interest in punishing defendants proportionately to their criminally culpable conduct. Accordingly, when a defendant has brought a successful collateral attack as a result of a change in the law, the prosecutor should be able to choose between resentencing and reinstating the indictment. While doctrines such as jurisdiction, due process, double jeopardy, and statutes of limitations may appear to present obstacles to such a course, a closer examination reveals that they are not dispositive. The flexible remedy defended by this Comment helps to ensure the proper relationship between the conduct and the sentence. 